OPEN ACCESS

University of Dundee

\title{
Institutionalisation of Emerging Norms of Customary International Law through Resolutions and Operational Activities of the Political and Subsidiary Organs of the United Nations
}

Droubi, Sufyan

Published in:

International Organizations Law Review

DOI:

$10.1163 / 15723747-01402002$

Publication date:

2017

Document Version

Peer reviewed version

Link to publication in Discovery Research Portal

Citation for published version (APA):

Droubi, S. (2017). Institutionalisation of Emerging Norms of Customary International Law through Resolutions and Operational Activities of the Political and Subsidiary Organs of the United Nations. International

Organizations Law Review, 14(2), 254-290. https://doi.org/10.1163/15723747-01402002

\section{General rights}

Copyright and moral rights for the publications made accessible in Discovery Research Portal are retained by the authors and/or other copyright owners and it is a condition of accessing publications that users recognise and abide by the legal requirements associated with these rights.

- Users may download and print one copy of any publication from Discovery Research Portal for the purpose of private study or research.

- You may not further distribute the material or use it for any profit-making activity or commercial gain.

- You may freely distribute the URL identifying the publication in the public portal.

Take down policy

If you believe that this document breaches copyright please contact us providing details, and we will remove access to the work immediately and investigate your claim. 
Link to final published version: 10.1163/15723747-01402002

\title{
Institutionalisation of Emerging Norms of Customary International Law through Resolutions and Operational Activities of the Political and Subsidiary Organs of the United Nations
}

\author{
Sufyan Droubi*
}

\begin{abstract}
The paper looks at resolutions and operational activities of the UN as parts of processes of institutionalisation of nascent norms of CIL. It argues that institutionalisation clarifies the scope of the norm and of its application; and improves mechanisms of persuasion and compliance with the norm, thereby increasing social pressure on resilient States. Hence, institutionalised norms have a higher potential to affect both the behaviour and attitude of States than noninstitutionalised norms. Crucially, the paper argues that UN resolutions and activities foster processes of institutionalisation of new norms. Although the work acknowledges that is not possible to foresee whether a norm will crystallise as CIL, it suggests that its potential increases if it matches and draws on the normative framework provided by the UN Charter, if it does not excessively challenge the predominant expectations of States, and if UN organs work together in promoting it.
\end{abstract}

\section{Keywords}

United Nations; International Organizations; International Law Commission; Customary International Law; Institutions; Constructivism

\footnotetext{
* Postdoctoral Research Fellow, School of Law, University of São Paulo. The research in connection with this article is funded by the São Paulo Research Foundation - FAPESP (grant 2015/24219-7), and a significant part of it was carried out at the Manchester International Law Centre, School of Law, University of Manchester. Contact: sufyan@usp.br. ORCID: 0000-0001-9749-6388.
} 


\section{Introduction}

In certain cases, the practice of international organizations also contributes to the formation, or expression, of rules of customary international law. ${ }^{1}$

A resolution adopted by an international organization ... may provide evidence for establishing the existence and content of a rule of customary international law, or contribute to its development. $^{2}$

Some decades ago, Higgins carried out a major effort to describe how the political organs of the United Nations ('UN') fostered the development of customary international law ('CIL'). ${ }^{3}$ On the one hand, Higgins emphasised the role of resolutions of political organs in clarifying and promoting the development of new CIL. ${ }^{4}$ On the other hand, she turned to the "methods by which states come to be bound by developing norms". ${ }^{5}$ The present paper is mostly concerned with these 'methods'.

Higgins started by highlighting that "constitutional provisions and the practical realities" were important for "securing behavioural compliance". ${ }^{6}$ Acknowledging that compliance was not the same as opinio juris, Higgins argued that there was a close relationship between the two concepts. ${ }^{7}$ Let us call this method, which affects compliance and opinio juris, as 'Method I'. I argue that it is closely related to another method that she described, namely, the generation of "specific pressures to submit reports and information on certain matters"8 ('Method II'). Further, Higgins emphasised the responsibility that falls upon members to cooperate in fulfilling the obligations arising from the Charter of the United Nations' ('Method III'). Likewise, she underlined the

${ }^{1}$ UN International Law Commission ('ILC'), 'Text of the draft conclusions on identification of customary international law adopted by the Commission', in Report on the Work of the Sixty-Eighth Session, UN Doc A/71/10 (19 August 2016), 76 [62], Conclusion 4 (2). (Hereinafter 'Draft Conclusions')

2 Ibid 78 [62] Conclusion 12 (2).

3 R Higgins, The Development of International Law through the Political Organs of the United Nations (Oxford University Press, New York, 1963); R Higgins, 'The Development of International Law by the Political Organs of the United Nations' (1965) 59 Proceedings of the American Society of International Law at Its Annual Meeting (1921-1969) 116-24; R Higgins, 'The United Nations and Lawmaking: The Political Organs' (1970) 64 The American Journal of International Law 37-48.

${ }^{4}$ Higgins (1965), ibid 121.

5 Ibid 123.

6 Ibid.

7 Ibid 124.

8 Ibid.

9 Ibid; Charter of the United Nations (hereinafter 'Charter'). 
"psychological pressure upon a government not to vote against a law-creating resolution if virtually all other states are likely to vote for it" ${ }^{10}$ ("Method IV'). Besides, she underscored "the intermingling in resolutions of developing norms with well-established rules"11 ('Method V'). These Methods broadly match similar descriptions that other scholars have made of the processes through which states change their behaviour and attitude or, technically, learn in international social processes. ${ }^{12}$ Finally, in her book, Higgins mentioned the role of the subsidiary organs of the UN in promoting new law ('Method VI'). In this latter respect, recalling the Congo Case, she asserted that "new institutional arrangements generate law and procedures" ${ }^{\prime 13}$ (which in a manner resonates with Method V). I argue that these 'methods' are mutually reinforcing and may be roughly organised as follows: Class A) Methods I to IV aim at changing the behaviour and attitude of states, notably through the generation of social pressure; and Class B) Methods V and VI aim at promoting the nascent norm through its institutionalisation, ie, its embedding in aggregates of norms and practices. As becomes clearer below, Class B Methods foster those in Class A.

Indeed, institutionalisation of a norm has a great potential to affect the behaviour and attitude of states because, inter alia, it promotes the clarification of the norm, enhances complianceinducing mechanisms, and fosters participation of different states in the law-making activity, all of which create social pressure on resilient states. In a well-known text, Charney describes a modern process of customary law-making, which he calls "general international law", ${ }^{14}$ and which he grounds on article 38 of the Statute of the International Court of Justice. ${ }^{15}$ Looking at the contribution of International Organizations ('IOs') towards the development of CIL, Charney argues that the creation of CIL has become "more structured ... specially in the case of important normative developments". ${ }^{16}$ In an attempt to systematise the description of the process of creation of CIL,

${ }^{10}$ Higgins (1965), above n 3, 124. Cf with A Wendt, 'Collective identity formation and the international state' (1994) 88(2) The American Political Science Review 384 (who argues that states "form identities by learning, through interaction, to see themselves as others do" and "the more significant these others are ... the faster and deeper the process works").

${ }^{11}$ Higgins (1965), above n 3, 124.

${ }^{12} \mathrm{~J}$ I Charney, 'Universal International Law' (1993) 87(4) American Journal of International Law 529-32. (The author asserts that "states collectively and severally maintain an interest in encouraging law-abiding behaviour" and that "fear of sanctions, the desire to be viewed by others as law-abiding, and domestic institutional inclinations to conform to rules denominated as law further impel states to comply"). Further, generally, see Wendt, above n 10, 384, (explaining that states learn their identities and interests in the social relations).

${ }^{13}$ Higgins (1965), above n 3, 4.

${ }^{14}$ Charney, above $\mathrm{n} 12,546$ (emphasis in original).

15 Ibid: "The use of this label [general international law] appears to be consistent with article 38 ... since 'international custom' is only 'evidence of a general practice accepted as law"' (emphasis in original).

${ }^{16}$ Ibid 543. 
Charney proposes that a norm may emerge and gain strength in a multilateral forum before the norm's diffusion and augmentation outside that forum. Indeed, he outlines the following order to these events: articulation of new norms in reports, resolutions, draft treaties etc; debate about the norm within the multilateral forum in question; communication to states present in the forum that the norm in question is intended to have legal character; diffusion of the norm to interested states outside the original forum; further debate about the norm that confirms "the normative status of the rule"; ${ }^{17}$ increasing voluntary compliance with the new norms that crystallises it as CIL. ${ }^{18}$ Charney clearly asserts that this is a deliberative process very close to the legislative process in domestic systems. ${ }^{19}$

What Charney describes may look like mere aspects of the law-making activity that occurs at the level of IOs. I prefer to look at the outline that he presents as a general depiction of a process of institutionalisation of international norms, and I am concerned with the effects that this process has on the strengthening of the norm and on the behaviour and attitude of the states. According to Charney, this new process is more democratic and more transparent than traditional customary law-making, and provides states with real opportunities to oppose the development of new norms ${ }^{20}$ it is less amenable to abuses than traditional customary law-making; ${ }^{21}$ it allows for the effective communication that new norms are under consideration; ${ }^{22}$ it may replace traditional customary law-making in respect to "matters with pronounced lawmaking potential" 23 and in matters of technical character, ${ }^{24}$ and its outcomes are "endowed with substantial legitimacy, creating a strong pull toward compliance". ${ }^{25}$ What is more, this process "greatly extends the international community's ability to clarify the intended scope and applicability of the norm under consideration". ${ }^{26}$

From one perspective, both Higgins' 'methods' and, notably Charney's process of lawmaking of 'general international law' may be studied on the assumption that IOs are mere agents

17 Ibid 546.

18 Ibid 543-546

19 Ibid 547. Cf with J E Alvarez, International Organizations as Law-makers (Oxford University Press, 2006) 594 (arguing that the process "approximates the intentional process involved in treaty-making") and, generally, chapters 3,4 , and 10 .

${ }^{20}$ Charney, above n 12, 547. See below nn 79, 82 and accompanying text.

${ }^{21}$ Ibid 548. See below nn 82, 94 and accompanying text.

22 Ibid 549. See below nn 91-97 and 129-131 and accompanying text.

23 Ibid.

${ }^{24}$ Ibid 550. See below nn 28 to 30 and accompanying text. See below Section 2.1.1.

25 Ibid.

${ }^{26}$ Ibid. 
of the states. ${ }^{27}$ However, this understanding overlooks the intensity of the behavioural and attitudinal changes that these 'methods' and 'new law-making' often inflict on states. In contrast, I suggest that we approach these 'methods' and 'new law-making' as interconnected social processes in which states continually learn to identify themselves, redefine their interests in respect to specific problems and, consequently, adopt new norms of behaviour. I argue that, from this second perspective, the analysis sheds light on the manners through which IOs promote the formation of CIL. Specifically, in the present article, I place focus on the processes of institutionalisation of emerging norms of CIL through the work of the political and subsidiary organs of the UN, and on the effects of this institutionalisation on the norms and on the states. As it develops, institutionalisation clarifies the scope of the norm and of its application; it improves mechanisms of persuasion, as well as enhances the monitoring of levels of compliance with the norm, thereby increasing cultural and social pressure on resilient states; in addition, it may promote the specialisation of the norm as a legal rule of CIL. As I explain below, resolutions and activities are an important part of processes of institutionalisation of new norms.

Before proceeding, it is critical to provide the contours of the contexts that are at the core of the subject of research. These are contexts in which the identities and interests of states are not stabilised and through which institutions experience ongoing change. In the present-day world, it is reasonable to assume that the institutions, as well as the individual and collective identities and interests of states, at least in respect to human rights and international security—also on themes such as environment and climate change law and certain aspects of international economic laware far from stable. ${ }^{28}$ Moreover, these and similar topics require specialised knowledge and collective responses. This scenario affects the emergence of new norms in the field, and provides renewed opportunity for international organisations and certain non-state actors ('NSAs'), to influence the formation of new norms. Their participation in these processes has already been the

${ }^{27}$ Ibid (acknowledging that international organs do not have "independent legislative authority").

${ }^{28}$ See, for instance, R Brooks, How Everything Became War and the Military Became Everything: Tales from the Pentagon (Simon and Schuster, 2016); N Klein, This Changes Everything: Capitalism vs. the Climate (Simon and Schuster, 2014); J Rapley, Twilight of the Money Gods: Economics as a Religion and How it all Went Wrong (Simon and Schuster, 2017). The authors describe what-I submit—can be defined as the building of collective identities: cf with E Adler and M Barnett (ed), Security Communities, 62 Cambridge Studies in International Relations (Cambridge University Press, 1998), especially chapters 2 and 12. Also, illustrating the instability international institutions face; Munich Security Conference, 'Munich Security Report 2017, Post-Truth, Post-West, Post-Order?' (23 February 2017) $<$ https://www.securityconference.de/en/discussion/munich-security-report/munich-security-report2017/>. 
subject of scholarly work. ${ }^{29} \mathrm{I}$ argue that, in many cases, their participation is a necessary condition for the norm to emerge and develop. ${ }^{30}$ Because of the instability of the context, the need of specialised knowledge and of collective responses, IOs offer focal points for the definition of problems, and articulation and promotion of new behaviours and attitudes-making the process of learning by states less traumatic. Furthermore, this instability has a clear impact on the organs of states and IOs involved in fomenting new norms, as the organs may face sharp criticism and challenges on grounds of lack of mandate or legitimacy. Again, IOs, through their procedures, can absorb these pressures and respond to them through the improvement and fine-tuning of the scope of the norms and procedures for their implementation. To address the formation of CIL in these contexts, the present work distances itself from the principal-agent theory that reduces IOs to agents of states, and from traditional rationalist approaches, which may provide good explanations of norm- and institution-formation in contexts in which the identities and interests of states are relatively stable.

This paper thus draws on the constructivist school, ${ }^{31}$ as well as on the constructivistinstitutionalist school, ${ }^{32}$ and combines them with Hartian approaches to international law. ${ }^{33}$ The

$29 \mathrm{~J}$ d'Aspremont, Participants in the International Legal System: Multiple Perspectives on Non-State Actors in International Law (Taylor and Francis, 2011).

${ }^{30}$ What comes to mind is the important role that the International Committee of the Red Cross performed in promoting rules of humanitarian law. See J M Henckaerts and L Doswald-Beck, Customary International Humanitarian Law (Cambridge University Press, 2005).

$31 \mathrm{~J} \mathrm{~T}$ Checkel, 'The Constructive Turn in International Relations Theory' (1998) 50 World Politics 324 327. (The author explains that neoliberalism and neorealism [which rest on rationalist grounds] are "agent-centred views" that "assert that all social phenomena are explicable in ways that involve only individual agents and their goals and actions; the starting point of the analysis is actors (states) with given properties. Ontologically, the result is to reduce one unit of analysis—structures- to the otheragents". He further notes that "constructivists do not reject science or causal explanation; their quarrel with mainstream theories is ontological, not epistemological". Furthermore, for constructivists, the effects of norms "reach deeper: they constitute actor identities and interests and do not simply regulate behaviour"). Also, S Droubi, "The Role of the United Nations in the Formation of Customary International Law in the Field of Human Rights' (2017) 19(1) International Community Law Review 68-97.

32 See C Hay, 'Constructivist Institutionalism' in Sarah A Binder, R A W Rhodes, and Bert A Rockman (eds), The Oxford Handbook of Political Institutions (Oxford University Press, 2008) 57 et seq. The author explains that "constructivist institutionalists were motivated by the desire to capture, describe, and interrogate institutional disequilibrium. As such, rational choice and normative/sociological institutionalism, which rely albeit for rather different reasons on the assumption of equilibrium, were theoretical non-starters" (emphasis in original).

33 See J d'Aspremont, 'Herbert Hart in Post-Modern International Legal Scholarship' (2012), in J Kammerhofer and J d'Aspremont (eds), International Legal Positivism in a Post-Modern World (Cambridge University Press, 2014) 114-50. (Drawing on Hart, d'Aspremont puts forward a dynamic theory of the sources of international law, which, inter alia, "helps show that cognising international law necessitates a theory of sources that is not static, but can rather evolve together with the social practice of law-applying 
paper firstly describes how institutionalisation works in the development of CIL (section 2). Then, in section 3, it shows how organs of the UN participate in the processes of institutionalisation of new CIL. Section 4 concludes.

\section{International institutions and the formation of CIL}

This section first clarifies some aspects of the terminology employed in the present work. Then, section 2.1 looks at institutionalisation of nascent CIL. Section 2.2 builds on section 2.1 and unveils fundamental aspects that allow section 3 to ascertain the role of UN resolutions and activities in promoting institutionalisation of new CIL.

Norms are standards of appropriate behaviour for a given identity. ${ }^{34}$ These standards could have a strict or general character (constituting, respectively, rules and principles). ${ }^{35}$ In the present text, rules and principles (to which I will refer indistinctively as rules) ${ }^{36}$ refer to norms that undergo the process of legal institutionalisation and that, consequently, can be formally articulated as legal rules. ${ }^{37}$ Hence, the words-'rules' and 'legal rules'-are used indistinctively. Moreover, institutionalisation can be defined as the process of embedding new norms in coherent aggregates of norms and practices. ${ }^{38}$ This concept of institutionalisation presupposes that institutions are aggregates of norms and practices. ${ }^{39}$ However, this definition requires further clarification, specifically, on the degree of formalisation of institutions. ${ }^{40}$ Roughly speaking, at the lower level of formalisation, there are what can be identified as 'arrangements'; ${ }^{41}$ at the mid-level, there are

authorities", which is crucial for the theory that the present work articulates). See below n 66 and accompanying text.

${ }^{34}$ Droubi, above n 31, 71-72. See A Florini, 'The Evolution of International Norms' (1996) 40 International Studies Quarterly 363; M Finnemore and K Sikkink, 'International Norm Dynamics and Political Change' (1998) 52 International Organization 887; M Finnemore, 'Are Legal Norms Distinctive?' (1999) 32 NYU Journal of Internationall Law and Politics 699.

35 Droubi, above n 31, 71-2.

36 Similarly, Draft Conclusions, UN Doc A/71/10, 81, Conclusion 1, Commentary [2].

37 N MacCormick, Institutions of Law: An Essay in Legal Theory (Oxford University Press, 2009) 24: "We have arrived at the idea of a rule, that is, and explicitly articulated norm ... The case here is one in which the explicit articulation is made by a person who has a position of authority".

${ }^{38}$ Droubi, above n 31, 70.

${ }^{39} \mathrm{R}$ O Keohane, After Hegemony: Cooperation and Discord in the World Political Economy (Princeton University Press, 2005) 5; R O Keohane, International Institutions And State Power: Essays in International Relations Theory (Westview Press, 1989) 383.

40 R O Keohane, 'International Institutions: Two Approaches' (1988) 32(4) International Studies Quarterly 379-396; J Goldstein et al, 'Introduction: Legalization and World Politics' (2000) 54 International Organization 385-392.

${ }^{41}$ See MacCormick, above n 37, 35-36. 
'agencies ${ }^{42}$ or 'entities ${ }^{43}$ or 'organs', and at the top, there are-I submit-political and judicial organs that often occupy the highest levels of their respective bureaucracies. The latter two categories of institutions display increasingly rigid politico-legal mandates and processes of decision-making and enforcement—as well as stable financial conditions. ${ }^{44}$ In contrast with informal institutions and lower-level organs, higher-level organs are less amenable to significant changes. Consequently, these organs may be more resistant to the emergence of norms, notably if such norms seriously challenge the status-quo-than informal institutions and lower-level organs. As I explain below, this does not prevent lower-level organs from creating pressure on higherlevel organs to adopt emerging norms, which may generate a process of progressive strengthening of the norms. In the present work, to avoid confusion, I employ the term 'organ' or 'international organ', instead of 'agencies' or 'entities'. ${ }^{45}$ I may also refer to it by its name: General Assembly ('GA' or 'UNGA'), Security Council ('SC' or 'UNSC'), Secretary-General ('SG' or 'UNSG'), International Law Commission ('ILC'), Sanctions Committees, inter alia.

\subsection{Progressive institutionalisation of nascent CIL}

In their day-to-day affairs in the international sphere, to attain their respective objectives and carry out their respective mandates, organs of states and IOs articulate, promote, and use new norms. As mentioned, this process is cost-effective because it facilitates learning by states. ${ }^{46}$ It is often the case that, only after a norm has crystallised as a rule of CIL, an observer is capable of discerning, with the benefit of hindsight, that the first articulation of the norm by a given organ was crucial for the evolution of the norm, and that the use of the norm by different organs in different places was crucial for its crystallisation as CIL. As these processes evolve they leave traces of different kinds: scholars and practitioners regard these traces as evidence of the formation and existence of CIL. ${ }^{47}$ What follows is an outline of the different processes involved in the formation of CIL. This

42 Ibid.

43 Keohane, above n 40, 382-384.

${ }^{44}$ J G Ruggie, 'International Responses to Technology: Concepts and Trends' (1975) 29 International Organization 557-569; J G Ruggie, 'International Regimes, Transactions, and Change: Embedded Liberalism in the Postwar Economic Order' (1982) 36 International Organization 308-379; S D Krasner, 'Structural Causes and Regime Consequences: Regimes as Intervening Variables' (1982) 36 International Organization 185.

45 The term agency has a specific meaning in the Charter articles 57-59.

${ }^{46}$ Missing the potential that this 'new form' of 'generation' of CIL has, to spare states from the traumatic process of learning through mistakes (which too often involved resort to violence), Dupuy referred to the "modern" process as contoume sanvage. See R J Dupuy, 'Coutume Sage et Coutume Sauvage' in La Communauté Internationale: Mélanges Offerts À Charles Rousseau (A Pedon, 1974) 75-77.

47 Draft Conclusions, UN Doc A/71/10, 91, 99, Conclusions 6(2), 10(2). 
outline highlights institutions that push the norm forward. The account roughly follows the stages of emergence, cascade, and internalisation in the formation of a norm. ${ }^{48}$

\subsubsection{Emergence}

Specialised organs of states (such as national meteorological and hydrological services) and IOs (the Commission for Climatology of the World Meteorological Organization) are mandated with the task of addressing specific realities. They transform information into knowledge and define problems, frame solutions, and articulate prescriptions of behaviour. ${ }^{49}$ For instance, the organs above were involved with the definition of anthropomorphic climate change as a problem, and the articulation and promotion of new prescriptions of behaviour for states to reduce emissions of greenhouse gases. ${ }^{50}$ In reality, not only national meteorological services but also other actors (eg, scholars, organisations of both national and international character) were responsible for the definition of climate change as problem that required a range of responses. Hence, the theory articulated in the present paper reflects only part of a very complex, decentralised and fragmented reality, which has been the object of different studies. ${ }^{51}$ Nevertheless, the contribution of non-state actors, whether domestic or not, are beyond the scope of the present article.

48 Finnemore and Sikkink, above n 34.

49 In respect to IOs, see the landmark study M Barnett and M Finnemore, Rules for the World: International Organizations in Global Politics (Cornell University Press, 2004) 29-31 (The authors argue that IOs are bureaucracies that enjoy autonomy and authority notably by controlling knowledge, ie, by providing meaning to raw information. Hence, they exercise power in respect to states and non-state actors, ie, they are capable of shaping the ability of those actors to "determine their own circumstances and fate". They not only "manipulate incentives to shape the behavior of those actors", but they also are capable of creating, defining and mapping social realities in which the interests of states are constructed. The authors identify three mechanisms through which IOs regulate and constitute the world: they "classify the world, creating categories of problems, actors and action; fix meaning in the social world; and articulate and diffuse new norms and rules").

50 See, generally, World Meteorological Organization, Proceedings of the World Climate Conference-A Conference of Experts on Climate and Mankind. Geneva 12-13 February 1979, WMO No 537 (20 February 2017) <http://library.wmo.int/pmb_ged/wmo_537_en.pdf>, notably at 713-714 (inter alia, representatives of national meteorological services were present at the Conference, whose outcome, in the form of a formal declaration, clearly defined that "Man [sic] today inadvertently modifies climate on a local scale and to a limited extent on a regional scale. There is serious concern that the continued expansion of man's activities on earth may cause significant extended regional and even global changes in climate").

51 Notably, the incipient theory on regime complexes helps explaining the role of different actors, including domestic organs and civil society, in the development of international regimes (K Raustiala and D G Victor, 'The regime complex for plant genetic resources' (2004) 58(2) International Organization 277-309; R O Keohane and D G Victor, 'The Regime Complex for Climate Change' (2011) 9(1) Perspectives on Politics 7-23; A Orsini, J F Morin, and O Young, 'Regime Complexes: A Buzz, a Boom, or a Boost for Global Governance?’ (2013) 19(1) Global Governance: A Review of Multilateralism and International 
Given their mandate, very often the members of state organs are experts. In performing these tasks, organs of states and IOs often operate together, and are orientated towards problemsolving. In general, they have much room to devise new solutions. Consequently, their recommendations, when proposing new prescriptions of behaviour, may challenge the predominant expectations of the international community. For instance, many countries strongly resisted agreeing to any obligation to reduce industrial emissions by invoking their sovereignty. ${ }^{52}$ Because new prescriptions of behaviour arise within institutions, prescriptions carry with them the ethos of these institutions. On the one hand, this fact allows the new prescription to draw from the legitimacy of their original institutions; on the other, however, this fact frames the possible development of the prescription. In other words, institutionalisation is path-dependent: each move forward depends on the prior move, and frames possible future moves. ${ }^{53}$ Hence, the importance of the original institution must not be underestimated.

Furthermore, prescriptions of behaviour are not necessarily norms. The latter "embody a quality of oughtness and shared moral assessment, prompting justification for action". ${ }^{4}$ In other words, the norm emerges as the sense, that the prescription ought to be observed within the international community of States, crystallises. ${ }^{55}$ Note that the articulation of the prescription, by (specialised) organs of states and IOs working in coordination, helps in explaining why learning by states has become faster and less traumatic in contrast to the 'old form' of generation of CIL. Further, one particular actor becomes important in the promotion of the prescription as a norm;

Organizations 27-39). Some of these studies have also contributed a transnational analysis ( $\mathrm{K} \mathrm{W}$ Abbott, 'The Transnational Regime Complex for Climate Change' (2012) 30(4) Environment and Planning C: Government and Policy 571-590). In any case, regime complexes theories place focus on regimes and governance. They provide only partial relief for the study of the development of norms, which makes clear that further studies are necessary to understand how these theories may contribute for the ascertainment of the role that domestic state and non-state actors have in the formation of international norms.

${ }^{52} \mathrm{M}$ Betsill, 'Environmental NGOs meet the sovereign state: The Kyoto protocol negotiations on global climate change' (2002) 13 Colorado Journal of International Environmental Law and Policy 13, 49.

${ }^{53}$ J G March et al, 'The Institutional Dynamics of International Political Orders' (1998) 52 International Organization 943. Similarly, Alvarez, above n 19, 265.

${ }^{54}$ Finnemore and Sikkink, above n 34, 892.

55 Cf with Draft Conclusions, UN Doc A/71/10, 87, Conclusion 3, Commentary [9]: "While in the identification of a rule of customary international law the existence of a general practice is often the initial factor to be considered, and only then an inquiry is made into whether such general practice is accepted as law, this order of inquiry is not mandatory. The identification of a rule of customary international law may also begin with appraising a written test or statement allegedly expressing a certain legal conviction and then seeking to verify whether there is a general practice corresponding to it". 
the norm-entrepreneur. ${ }^{56}$ This having been said, it is important to note that another class of organs and institutions often intervene in the process that leads to the emergence of a norm in the international community of states - namely, organs and institutions that occupy the highest levels of their respective bureaucracy. ${ }^{57}$ Because they represent their respective states and IOs, it is possible to affirm that such states and IOs have formally adopted the norm. Hence, at this very incipient stage, technical institutions and organs, norm-entrepreneurs and political organs intervene to push the norm forward to the next stages.

\subsubsection{Cascade}

The first group of states that support the norm constitute the 'leading states', which are important because they create social pressure on other states. Consequently, in different states and IOs, organs and institutions intervene by adopting the new norm. This process accelerates the clarification of the scope of the norm and the promotion of its implementation. Leading states become concerned about securing compliance from other states and, to that end, they adopt a more specialised language and employ more specialised institutions. Their argumentation in favour of the norm becomes marked by the use of legal topoi, ${ }^{58}$ forcing resilient states to resort to legal argumentation as well. Likewise, leading states promote the insertion of the norm into formal institutions designed to induce compliance with the norm. As language and institutionalisation become highly specialised, it becomes possible to identify a nascent rule of law. In some cases, it is clear that a rule of law has emerged. For instance, states may decide to enter into a treaty that

56 Cf with Draft Conclusions, UN Doc A/71/10, 90 Conclusion 4(3), Commentary [9]: "the acts of private individuals may also sometimes be relevant, but only to the extent that States have endorsed or reacted to them". See Sections 3.1.2 and 3.1.3.

57 This is not meant to resuscitate the "older position, according to which only the actions of those designated to represent the state externally ("international organs of a State") may count as State practice", which "is no longer generally accepted" (M Wood, 'Second Report on Identification of Customary International Law', UN Doc A/CN 4/672 (22 May 2014) 17). Rather, this is meant to suggest that the involvement of the organs that occupy the highest levels of the state bureaucracy is often necessary to show that the actions in question are performed out of a belief that there is an international norm requiring them. Cf with Draft Conclusions, UN Doc A/71/10, 90, Conclusion 5, Commentary [2] ("The conduct of any State organ is to be considered conduct of that State, whether the organ exercises legislative, executive, judicial or any other functions, whatever position it holds in the organization of the State, and whatever its character as an organ of the central Government or of a territorial unit of the State") and 92, Conclusion 6, Commentary [6] ("Decisions of national courts at all levels may count as State practice (though it is likely that greater weight will be given to the higher courts")). However, see below n 90 and accompanying text.

58 Cf with F V Kratochwil, Rules, Norms, and Decisions: On the Conditions of Practical and Legal Reasoning in International Relations and Domestic Affairs (Cambridge University Press, 1991) 38-41, 218-219, $234-235$. 
sets forth the rule and establishes a monitoring mechanism of compliance. ${ }^{59}$ In other cases, such as that of CIL, further confirmation of lawfulness is necessary. Hence, at the cascade stage, political and technical institutions in different states and IOs, which are capable of inducing compliance with the norm, intervene. As language becomes increasingly formalised, states and IOs issue formal declarations supporting or rejecting the new rule.

\subsubsection{Internalisation}

It is crucial to examine the concept of internalisation. Finnemore and Sikkink emphasised the total internalisation of norms by the state, and consequently they placed it at the end of the norm cascade. $^{60}$ In contrast, the concept of internalisation that I adopt emphasises the progressive internalisation of the norm as a rule of law, ${ }^{61}$ and considers the importance of international and domestic organs and institutions in pushing other organs of a given state to adopt the norm, in a manner that makes the practice and opinio juris of the state in question progressively clear. ${ }^{62}$ Governments may do so by affirming the norm as a rule of law through statements and favourable voting at different fora, diplomatic acts and communications, and the signing and ratification of treaties. Moreover, they may direct lower organs to comply with and implement the rule, in which case the latter is implemented on the ground. Parliaments may also incorporate the rule into domestic legislation and courts and tribunals, enforce it through judicial mechanisms. Note, however, that internalisation of the norm begins at a much earlier stage, ie, at the emergence stage, when the norm was nothing more than a prescription. This is because the technical organs involved at the earlier stage were likely to be in contact with their equivalents from other countries and from IOs. In other words, in this perspective, lower institutions promote the formal

\footnotetext{
${ }^{59}$ Finnemore and Sikkink, above n 34, 900.

${ }^{60} \mathrm{Ibid}$ 904-905: "At the extreme of a norm cascade, norms may become so widely accepted that they are internalised by actors and achieve a 'taken-for-granted' quality that makes conformance with the norm almost automatic. For this reason, internalised norms can be both extremely powerful (because behaviour according to the norm is not questioned) and hard to discern (because actors do not seriously consider or discuss whether to conform). Precisely because they are not controversial, however, these norms are often not the centrepiece of political debate and for that reason tend to be ignored by political scientist". In the same vein, see Droubi, above n 31, 84-85.

${ }^{61}$ Similarly, H H Koh, 'Internalization through Socialization' (2005) 54(4) Duke Law Journal 975.

${ }^{62}$ See above n 57 and accompanying text.
} 
internalisation of the norm by the elite organs of the state. ${ }^{63}$ Evidently, while this process is in flux, it is difficult, if at all possible, to distinguish a uniform practice of the state. ${ }^{64}$

\subsubsection{Late cascade}

As the process evolves into late cascade, a specific class of actors, international legal authorities (or legal officials) such as courts and tribunals, renowned jurists, professional associations, ${ }^{65}$ may be able to affirm the new norm is CIL, to strongly suggest that it is CIL, or simply to employ it as CIL. ${ }^{66}$ From an analytical standpoint, the authority works in different manners. Formally, it gives closure to past processes because it ascertains the existence of a rule of CIL, which is typically a lawapplying activity. Moreover, the affirmation of the authority — that a rule is CIL-may shed light on a reality — the rule is CIL—that had not been clear to all states. ${ }^{67}$ In this case, the affirmation makes it possible for States to see the rule in question as CIL, which in turn strengthens the rule. Hence, the affirmation may have a performative effect on the behaviour and attitude of states. ${ }^{68}$

${ }^{63}$ Evidently, there are alternative routes as the elite may force a new norm down to state institutions and civil society. See J T Checkel, 'Why Comply? Social Learning and European Identity Change' (2001) 55 International Organization 553.

${ }^{64}$ Cf with Draft Conclusions, UN Doc A/71/10, 93, Conclusion 7(2), Commentary [4]: "where different organs or branches within the State adopt different courses of conduct on the same matter or the practice of one organ varies over time" the practice of the state is inconsistent and its "contribution to the 'general practice' element may be reduced or even nullified". In contrast, see the statement made by Shinya Murase: "paragraph $2 \ldots$ appeared to disregard the fact that it was quite normal within democratic countries for State organs to express conflicting views", in 'Provisional Summary Record of

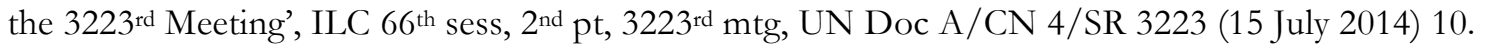

65 The concept is borrowed from Tamanaha: "a 'legal' official is whomever, as a matter or social practice, members of the group (including legal officials themselves) identify and treat as 'legal officials"'. B Z Tamanaha, A General Jurisprudence of Law and Society (Oxford University Press, 2001) 14. Also, d'Aspremont, above n 29. Similarly, M S McDougal, 'Law and Peace' (1989) 18 Denver Journal of International Law and Policy 1-2.

66 Drawing on the dynamic theory of the sources of international law (see above n 33), I argue that the possibility of affirming that a rule is CIL depends on the evolution of the 'feeling' that legal authorities share about what CIL is and about how it must be ascertained. Furthermore, I submit that the institutionalisation of the evolving norm affects legal authorities as much it affects states.

${ }^{67}$ Reviewing Fisheries Jurisdiction (United Kingdom v Norway) (Judgment) [1951] ICJ Rep 116, Charney explained that the ICJ affirmed that CIL required certain behaviours from states; however, he concluded: "None of these requirements was clearly articulated and known to the international community prior to the Court's declaration. Nevertheless, these rules were found to be public international law": Charney, above n 12, 537.

68 Similarly, I Venzke, 'The Role of International Courts as Interpreters and Developers of the Law: Working out the Jurisgenerative Practice of Interpretation' (2011) 34 Loyola of Los Angeles International and Comparative Law Review 99. On performative speech, see generally J L Austin, How to Do Things with Words (Oxford University Press, 1975); J R Searle, Speech Acts: An Essay in the Philosophy of Language 
Furthermore, the authority may frame the future development of the norm. ${ }^{69}$ This latter case becomes salient in situations in which the affirmation that a given rule is CIL is premature, and attracts support as much as it triggers opposition —as the affirmation made by the Special Tribunal for Lebanon, that terrorism is a crime in international law, evidences. ${ }^{70} \mathrm{I}$ argue that the first authoritative affirmation or affirmations of the norm as CIL tend to constitute a landmark phenomenon that seemingly closes the early stages of the formation of the norm. Further, I submit that the first affirmations of CIL are on the blurred lines between law-making and law-applying. Hence, at late cascade, highly specialised institutions, like judicial and quasi-judicial organs, intervene in support of the norm.

I also argue that UN organs and institutions are important participants in the processes above. However, in order to properly understand their role, it is necessary to recall some fundamental aspects of formation of CIL.

\subsection{Aspects of fundamental importance for understanding the role of international organs and institutions in the life-cycle of a norm}

First, I emphasise that the predominant understanding is that a rule is CIL if it is grounded in the behaviour and attitude (opinio juris) of states. ${ }^{71}$ Despite its normative significance, this definition only guides the practice of ascertaining the existence of CIL. Indeed, although the two elements are formally necessary for the rule to constitute $\mathrm{CIL},{ }^{72}$ often it is not possible, notably at the earlier stages of formation of the CIL (emergence and early cascade), to clearly distinguish one from the

(Cambridge University Press, 1969). On a different perspective, P Bourdieu, 'The Force of Law: Toward a Sociology of the Juridical Field' (1986) 38 Hastings Law Journal 805. The latter clearly derives the force of performative speech from the social authority of the speaker.

69 Cf with Draft Conclusions, UN Doc A/71/10, 110, Conclusion 13, Commentary [3]: “judicial pronouncements on the state of customary international law do not freeze the development of the law, rules of customary international law may have evolved since the date of a particular decision". Also, above $\mathrm{n} 53$ and accompanying text.

70 Droubi, above n 31, 80 [59].

${ }^{71}$ Draft Conclusions, UN Doc A/71/10, Conclusion 2: "To determine the existence and content of a rule of customary international law, it is necessary to ascertain whether there is a general practice that is accepted as law". Also important: acceptance of the norm is "required only by the international community and not by all individual states": Charney, above n 12, 536.

72 North Sea Continental Shelf (Federal Republic of Germany v Denmark; Federal Republic of Germany v Netherlands) (Judgment) [1969] ICJ Rep 3, 44 [77]: "Not only must the acts concerned amount to a settled practice, but they must also be such, or be carried out in such a way, as to be evidence of a belief that this practice is rendered obligatory by the existence of a rule of law requiring it". Similarly, Draft Conclusions, UN Doc A/71/10, 83, Conclusion 2 and Commentary [2]. 
other. ${ }^{73}$ They arise as a single reality and must be ascertained together. ${ }^{74}$ Likewise, at these stages, opinio juris shows itself as an (individual and collective) attitude that is favourable to the full emergence of the rule (notably, at early cascade) ${ }^{75}$ and this progressively acquires more salience as the new norm becomes part of more specialised institutions (internalisation and late cascade). Insofar as resilient states learn to understand certain realities as problems (late emergence, early cascade), and accept that they need to change their behaviour to tackle these problems, new attitudes emerge.

Second, formation of new CIL is markedly a political process, which progressively acquires legal character. ${ }^{76}$ I argue that at the stages of emergence and early cascade of new CIL, it is very difficult, if not impossible, to clearly distinguish between the political (or moral: the non-law) and the law. ${ }^{77}$ Moreover, even at mature stages, "political considerations must be taken into account

73 Droubi, above n 31, 78 et seq; Cf with Draft Conclusions, UN Doc A/71/10, 83, Conclusion 2, Commentary [3]: "where the existence of a general practice accepted as law cannot be established, the conclusion will be that the alleged rule of customary international law does not exist".

${ }^{74}$ Droubi, above $\mathrm{n} 31,78$ : "rather than assessing whether the practice of organs of one state is uniform in supporting the norm, the appropriate exercise for the ascertainment of the formation of a customary international legal rule requires an assessment of the reasons for actions taken by the different organs". Cf with Colombian-Peruvian Asylum (Judgment) [1950] ICJ Rep 266, 277: "The facts brought to the knowledge of the Court disclose so much uncertainty and contradiction, so much fluctuation and discrepancy in the exercise of diplomatic asylum and in the official views expressed on various occasions, there has been so much inconsistency in the rapid succession of conventions on asylum, ratified by some States and rejected by others, and the practice has been so much influenced by considerations of political expediency in the various cases, that it is not possible to discern in all this any constant and uniform usage, accepted as law, with regard to the alleged rule of unilateral and definitive qualification of the offence".

${ }^{75}$ See Droubi, above n 31, 81 et seq.

${ }^{76}$ Charney, above n 12, 539: "Customary law results from political decisions to take the steps necessary to form a rule".

77 Castañeda employs the expression "quasi-legal" to describe the "amorphous and mobile reality of this legal sector", in which "there are no tangible, clear, juridical criteria to demarcate with precision the zones of binding force": J Castañeda, Legal Effects of United Nations Resolutions (Columbia University Press, 1969) 176. Similarly, Alvarez, above n 19, 258: "Although the doctrine of article 38 sources recognises no "in-between" category in terms of legally binding effect, this is the category in which much of the regulatory work of these IOs fits". More recently, there have been significant developments that permit a better understanding of this "amorphous and mobile reality". Judge Simma differentiated between degrees of non-prohibition: See Accordance with International Law of the Unilateral Declaration of Independence in Respect of Kosovo (Advisory Opinion) [2010] ICJ Rep 403, 478-481 especially at [9] (Declaration of Judge Simma). S Droubi, 'Transnational Corporations and International Human Rights Law' (2015) 6 Notre Dame Journal of International and Comparative Law 131-132. Also, MacCormick, above n 37, 103 et seq (the author differentiates between Wrong and Not-Wrong). Finally, F Johns, Non-Legality in International Law-Unruly Law (Cambridge University Press, 2013). 
when interpreting ambiguous or imprecise rules". ${ }^{78}$ Hence, the ascertainment of CIL is a politicolegal process. This constitutes another challenge for practitioners and authorities to strictly follow the definition of CIL when ascertaining the existence of CIL. Indeed, the legitimate affirmation of a norm as CIL does not require that legal authority carries out a sociological observation of the general behaviour and attitude of states. ${ }^{79}$ The authority will often ascertain the behaviour of some states and through normative reasoning give meaning to the behaviour of the others (eg, when the authority identifies acquiescence). Besides, the authority will often analyse their behaviour within the specific contexts and infer their attitude (opinio juris). ${ }^{80}$ Moreover, the authority will occupy itself of the behaviour and attitude of the main organs of the state-it will rarely attend to the behaviour of lower organs and, least of all, domestic non-state actors. ${ }^{81}$ Evidently, this causes a legitimacy deficit, as many states, and many domestic institutions within the same state, remain at the margins of the process. ${ }^{82}$

Further, collective expectations and social pressure may function either to strengthen or to weaken the potential of the emerging norm to evolve into CIL. Indeed, both Higgins and Johnstone show the weight that collective expectations have on the work of norm-entrepreneurs, ie, individuals who promote new norms. Recalling Schachter and Hammarskjöld, ${ }^{83}$ Higgins observed that the Secretary-General cannot depart too radically from the expectations of the community. ${ }^{84}$ That is exactly the same conclusion that Johnstone reached many decades later after a detailed examination of a case study in which the Secretary-General performed the role of a

78 Higgins (1963), above n 3, 9.

${ }^{79}$ Droubi, above n 31, 82-83. Likewise, Military and Paramilitary Activities in and against Nicaragua (Nicaragua $v$ United States of America) (Merits) [1986] ICJ Rep 14, 98 [186]: “The Court does not consider that, for a rule to be established as customary, the corresponding practice must be in absolutely rigorous conformity with the rule ... the Court deems it sufficient tha the conduct of States should, in general, be consistent with such rules". See below n 94 and accompanying text.

80 A A d'Amato, The Concept of Custom in International Law (Cornell University Press, 1971) 85. (The author reviews the Lotus case and concludes that the ICJ inferred "the subjective attitude on the part of the states concerned", arguing that although "substantially questionable", inference constitutes a "technique of proof of custom that is significant”. Similarly, Draft Conclusions, UN Doc A/71/10, 84, Conclusion 2, Commentary [5]. See below n 93 and accompanying text.

81 Droubi, above n 31, 84-85 (The level of internalisation is, in sociological terms, that of the "elites of the state").

${ }^{82}$ For all, J Castañeda, 'The Underdeveloped Nations and the Development of International Law' (1961) 15 International Organization 38.

83 See O Schachter, 'Dag Hammarskjöld and the Relation of Law to Politics' (1962) 56 The American Journal of International Law 1-6. Also, see the landmark study by the same author: 'The Development of International Law through the Legal Opinions of the United Nations Secretariat' (1948) 25 British Yearbook of International Law 91.

84 Higgins, above n 3, (1963) 8. 
norm-entrepreneur. ${ }^{85}$ Consequently, it is often the case that norms, which depart significantly from the expectations of the community, require more time to crystallise. Indeed, in a well-known text, Lauterpatch suggests that the period for the crystallisation of new CIL is proportionate to the degree and intensity of the change. ${ }^{86}$ Fitzmaurice adds that the passage of "an appreciable period of time" is essential if emerging rights are contrary to established law. ${ }^{87}$ However, this rule-ofthumb, requiring more time depending on the degree and intensity of change, does not seem to stand the test of unstable environments, notably when new CIL emerges from or is pushed forward by rapid onset events that trigger a general change of attitude. ${ }^{88}$ A case study on the impact that terrorist attacks in the US and other Western States in the 2000s had on the acceleration of the crystallisation of the prohibition of terrorism as CIL may illustrate this point.

85 I Johnstone, 'The Secretary-General as Norm Entrepreneur' in Simon Chesterman (ed), Secretary or General?: The UN Secretary-General in World Politics (Cambridge University Press, 2007) 123-138.

86 H Lauterpacht, 'Sovereignty over Submarine Areas' (1950) 27 British Yearbook of International Law 393: "A 'consistent and uniform usage practiced by the States in question'- to use the language of the International Court of Justice in the Asylum case-can be packed within a short space of years. The 'evidence of a general practice as law' - in the words of article 38 of the Statute-need not be spread over decades. Any tendency to exact a prolonged period for the crystallisation of custom must be proportionate to the degree and the intensity of the change that it purports, or is asserted, to effect".

87 G Fitzmaurice, 'The Law and Procedure of the International Court of Justice, 1951-4: General Principles and Sources of Law' (1953) 30 British Yearbook of International Law 31: "the acquisition of prescriptive rights by individual States, contrary to the existing (and otherwise still subsisting) international order, involves different considerations and criteria, that make the passage of time, and of an appreciable period of time at that, essential at any rate in all those cases (which are the type of the true prescriptive or historic claim) where the positive consent or express recognition of States cannot be shown".

88 The important criterion seems to constitute that put forward by the ICJ in North Sea Continental Shelf (Federal Republic of Germany v Denmark; Federal Republic of Germany v Netherlands) (Judgment) [1969] ICJ Rep 3, 43 [74]: "Although the passage of only a short period of time is not necessarily, or of itself, a bar to the formation of a new rule of customary international law on the basis of what was originally a purely conventional rule, an indispensable requirement would be that within the period in question, short though it might be, State practice, including that of States whose interests are specially affected, should have been both extensive and virtually uniform in the sense of the provision invoked;- and should moreover have occurred in such a way as to show a general recognition that a rule of law or legal obligation is involved". Moreover, see ibid 242, Dissenting Opinion of Judge Sorensen, 244: "The convention may serve as an authoritative guide for the practice of States faced with the relevant new legal problems, and its provisions thus become the nucleus around which a new set of generally recognised legal rules may crystallise. The word 'custom', with its traditional time connotation, may not even be an adequate expression for the purpose of describing this particular source of law". In the same vein, Alvarez, above n 19. 
In the informal process of creation of CIL, is there any formal act that may indicate the move from politics to law? d'Amato drew on the concept of 'promulgative communication ${ }^{89}$ when he proposed the concept of promulgative articulation: ie, articulation that gives notice to states that their "actions and decisions will have legal implications" so states may "be able to freely decide whether or not to pursue various policies, knowing that their acts may create or modify international law". ${ }^{90}$ Which 'legal implications'? Unfortunately, the formalist approach adopted by d'Amato misses some of them.

I argue that promulgative articulation involves the use of the norm in contexts that suggests to states that their behaviour, in respect to the norm, may be described and should be justified in legal terms. In other words, it permits that leading states and IOs ascertain the behaviour of resilient states pursuant to legal topoi and, notably, principles of law. ${ }^{91}$ Legal topoi profoundly mark legal reasoning and argumentation, ${ }^{92}$ and they provide the lenses through which the behaviour of noncompliant states are likely to be ascertained. Principles of law foster the generation of CIL, by providing a material behaviour with legal meaning. ${ }^{3}$ Hence, silence may trigger acquiescence with

89 M S McDougal, H D Lasswell, W M Reisman, 'The World Constitutive Process of Authoritative Decision' (1967) 19 Journal of Legal Education 253-424: "Processes of prescription occur in a wide variety of situations and the degree of institutionalisation of the various component processes of prescription varies greatly. The sequence of a completed process of prescription is: (i) initiation; (ii) exploration of potentially relevant facts and policies; (iii) formulation, that is the characterization of the facts and policies accepted as relevant; and (iv) promulgative communication of the prescriptive content to the target audience (emphasis added)".

90 D'Amato, above $\mathrm{n} 80,75$. D'Amato made it clear that "third parties" could participate in the promulgation of the rule: "But it must be promulgated in a place which nation-state officials and their counsel would have reason to consult"; ibid 85. Similarly, Draft Conclusions, UN Doc A/71/10, 98, Conclusion 9, Commentary [5]: "[states in a position to react to a practice] must be shown to have understood the practice as being in accordance with customary international law". Also, Military and Paramilitary Activities in and Against Nicaragua (Merits) [1986] ICJ Rep 14, 109 [207]: "Either the States taking such action or other States in a position to react to it, must have behaved so that their conduct is 'evidence of belief that this practice is rendered obligatory by the existence of a rule of law requiring it"' (emphasis added). Moreover, Draft Conclusions, UN Doc A/71/10, 99 Conclusion 10(3) and Commentary [1], [4], and [7]. Furthermore, Sovereignty over Pedra Branca/ Pulau Batu Puteh, Middle Rocks and South Ledge (Malaysia $v$ Singapore) (Judgment) [2008] ICJ Rep 12, 50-51 [121]: "silence may also speak, but only if the conduct of the other State calls for a response". Note how the present aspect subtlety relates to above $\mathrm{n} 80$ and accompanying text.

${ }^{91}$ Kratochwil, above n 58, 39 (the author notes that legal topoi justify the exlusion of many "practical arguments" in a "discourse on grievances" and limit the "range of relevant facts and proofs"). Similarly, d'Amato, above n 80, 175.

92 See, generally, T Viehweg and L Díez-Picazo, Tópica y Jurisprudencia (Thomson-Civitas, 2007). Kratochwil, above n 58, 218-219.

${ }^{93}$ See R Kolb, 'Principles as Sources of International Law (with special reference to good faith)' (2006) 53 Netherlands International Law Review 1-7. 
the new norm; ${ }^{94}$ material compliance, ie, compliance resulting from social pressure and not accompanied by the belief that the norm is law, may activate the principle of equitable estoppel. ${ }^{95}$ The latter principle may be activated by strong statements that may not be accompanied by the willingness to comply, that is, by 'cheap talk'. However, this case unveils other factors of politicolegal character that make it difficult for the state not to meet word with deed. ${ }^{96}$ Finally, I submit that promulgative articulation may involve one specific phenomenon, namely, the inversion of the burden of proof in favour of the norm. ${ }^{97}$ Thenceforth, resilient states will face pressure to justify their behaviour (similar to what occurs through Higgins' Methods I and II).

Higgins argues that the political organs of the UN are "vitally concerned" with the development of CIL. ${ }^{98}$ Insofar as the organs operate within a normative structure (in this case, the main element of this structure is the Charter) and seek to attain the objectives ascribed to them in their respective mandates; they work under specific worldviews, promote understandings that match their worldviews, and demote others that do not. The problems that they define, the norms that they articulate and promote, they do so pursuant to their worldviews. This, by itself, strengthens certain norms and weakens others. ${ }^{99}$ The embedding of a norm (eg, prohibition of terrorism) in one institution (the international human rights system) ${ }^{100}$ marks the development of the norm in fundamental terms. How would the prohibition of terrorism have developed if it had not been embedded as a principle within the international human rights system, and left as a principle respecting solely national and international security? The fact — that a significant number of newly formed states rejected criminalising terrorism out of concern that they would criminalise the struggle against colonisation, ie, rejected criminalising terrorism because this criminalisation

${ }^{94}$ D’Amato, above n 80, 195-198. See Draft Conclusions, UN Doc A/71/10, 95, Conclusion 8, Commentary [3]: "A relatively small number of States engaging in a certain practice might thus suffice if indeed such practice, as well as other States' inaction in response, is generally accepted as law” (emphasis added). Note how this contributes to the characterisation of the work of the legal authority official, when it ascertains the existence of a rule, as politico-legal rather than a sociological exercise: see above $\mathrm{n} 79$.

95 D’Amato, ibid 199-215. Cf with T M Franck and D M Sughrue, 'The International Role of Equity-asFairness' (1992) 81 Georgetown Law Journal 563-596.

96 See Elster on the "civilizing force of hypocrisy": J Elster, Deliberative Democracy, (Cambridge University Press, 1998), especially 111 (Publicity of the debates foster the replacement of language of interest by the language of reason).

97 See below $\mathrm{n} 142$ and accompanying text.

98 Higgins, above n 3, (1963) 2. See also Alvarez, above n 19, chapters 3 and 4.

99 See above $\mathrm{n} 53$ and accompanying text

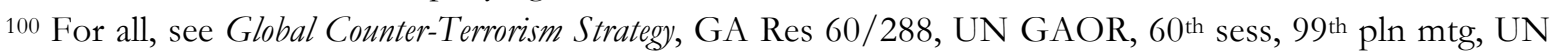
Doc A/RES/60/288 (8 September 2006), preamble: "Reaffirming that acts, methods and practices of terrorism in all its forms and manifestations are activities aimed at the destruction of human rights, fundamental freedoms and democracy". 
would undermine the principle of self-determination ${ }^{101}$ — suggests an answer to the former question.

Moreover, although formal institutions and organs are involved with formation of CIL, the latter constitutes an informal process. Indeed, international organs have their own mandates and often such mandates do not involve the task of fomenting the creation of CIL. Although certain organs have mandates that are broad enough to encompass the promotion of the formation of CIL, ${ }^{102}$ the process of formation is, in itself, informal—suffice to contrast it to the process of drafting, signing and ratifying treaties. In this perspective, I argue that the different mandates and structures of UN organs allow them to weigh in at different stages of the formation of CIL. For instance, although the nascent norm (eg, prohibition of apartheid, prohibition of torture) becomes part of institutions that may be highly formalised (Special Committee Against Apartheid, Committee Against Torture), the crystallisation of the norm as CIL is informal. In this process, different organs display different levels of potential in influencing different stages in the emergence of the norms as rules of CIL: the GA, inter alia, firmly fixed both prohibitions as norms, deeply enshrined them within the normative structure that arises from the UN Charter and provided ample legitimacy to the work of other organs, including other principal organs (whose mandates are more specialised); the Committees were thus capable of clarifying the scope of the prohibitions and were crucial in giving salience to noncompliance and generating social pressure. ${ }^{103}$ On this note, I argue that institutionalisation of a norm strengthens it and has a strong effect on the behaviour and attitude of states. Consequently, institutionalisation may promote the formation of new CIL. These processes are "consciously deliberative" 104 and path-dependent. ${ }^{105}$ However, neither an external observer nor the actors involved in the processes are capable of foreseeing or securing the emergence of the crystallisation of CIL. ${ }^{106}$

Evidently, certain organs of the state and IOs may understand that their decisions and actions may either improve or jeopardise the potential of the norm to become CIL. This allows them to act strategically. For instance, in January 1987, the President of the United States decided not to seek the advice and consent of the Senate for ratification of Protocol I to the 1949 Geneva

${ }^{101}$ See, generally, B Saul, 'Definition of "Terrorism" in the UN Security Council: 1985-2004' (2005) 4

Chinese Journal of International Law 141-66.

102 Such as the UNGA. See Charter, art 13(1)(a).

${ }^{103}$ Similarly, SC has more potential to affect some stages than others. See section 3.2.1 below.

104 See above $\mathrm{n} 19$ and accompanying text.

105 See above $n 53$ and accompanying text.

106 See Droubi, above n 31. 
Convention. ${ }^{107}$ The US Government acknowledged that "like all other efforts associated with the International Committee of the Red Cross" Protocol I "had certain meritorious elements". ${ }^{108}$ However, it asserted that "Protocol I is fundamentally and irreconcilably flawed". ${ }^{109}$ The President lamented that the document should be rejected. ${ }^{110}$ Nevertheless, the Government could "devise an alternative reference for the positive provisions of Protocol I that could be of real humanitarian benefit if generally observed by parties to international armed conflicts". ${ }^{111}$ The US Government intended to initiate consultations with its allies "to develop appropriate methods for incorporating these positive provisions into rules that govern our military operation, with the intention that they shall in time win recognition as customary international law separate from their presence in Protocol I". ${ }^{112}$ While the US Government intended to promote the collective institutionalisation of the provisions with the purpose of crystallising them as CIL, it could not guarantee that the objective would be attained. Hence, the point is that these organs may only bope to be able to affect the behaviour and the attitude of states. Depending on how much the behaviour and attitude of the latter changes, the new norms may acquire the character of CIL.

Nevertheless, it is possible, based on the above, to suggest some criteria for the identification of norms with the potential to become CIL. I argue that a norm displays this potential if it matches the normative framework of strong and well-established regimes, drawing significantly from their legitimacy and authority; when the norm does not challenge the expectations of states in manners that trigger the termination of the process of its own evolution, and when it is promoted through the combined efforts of organs of states and IOs.

107 Protocol Additional to the Geneva Conventions of 12 August 1949, and Relating to the Protection of Victims of International Armed Conflicts (Protocol I), opened for signature 12 December 1977, 1125 UNTS 3 (entered into force 7 December 1979).

108 United States, 'Message from the President of the United States Transmitting the Protocol $n$ II Additional to the Geneva Conventions of August 12, 1949, and Relating to the Protection of Victims of Noninternational Armed Conflicts, Concluded at Geneva on June 10, 1977', Senate, 100th Congress, ${ }^{\text {st }}$ sess (29 January 1987), Treaty Doc 100-2, iii.

109 Ibid.

110 Ibid iv.

111 Ibid.

112 Ibid x (emphasis added). See also T Meron et al, 'Customary Law and Additional Protocol I to the Geneva Conventions for the Protection of War Victims: Future Directions in Light of the US Decision Not to Ratify' (1987) 81 American Society of International Law Proceedings 26. (The panel formed by scholars, ICRC representatives and US officials discussed the reasons and implications of the decision of the US Government. Speaking on their individual capacity, US officials had the opportunity to identify the "meritorious provisions" of Protocol I that deserved becoming customary law). 


\section{Institutionalisation through the Resolutions and operational activities of the political organs of the UN}

Looking back at Higgins' Method VI and Charney's outline, and drawing on the above, I suggest that UN resolutions and activities may intervene in the formation of CIL, inter alia, as follows: (a) in their daily activities UN subsidiary organs and procedures may articulate a new prescription of behaviour, which (b) UN resolutions introduce as a norm to the international community; (c) UN organs may direct their subsidiary organs with the task of monitoring compliance with the norm and reporting back; (d) subsidiary, specialised organs intervene to appraise the behaviour and attitude of states in respect to the norm and make recommendations for the political organs to adopt in order to strengthen the norm; (e) their reports may be taken up by the principal organs, which may adopt more specific resolutions to tackle noncompliant behaviour; (f) UN organs may function as legal authorities and affirm the norm as CIL in judicial and quasi-judicial decisions and political resolutions. Note that this outline clarifies that resolutions may have three distinct functions: introduction and fixation of a new norm (item 'a'), fine-tuning of compliance-inducing mechanisms ('e') and affirmation of a new CIL ('f $).{ }^{113}$ Empirically, an observer should expect to verify that organs of the UN are in continuous contact with the organs of other IOs and of the states; and that states respond to the resolutions and activities either by adapting their behaviour to the norm or justifying their noncompliant behaviour. ${ }^{114}$ What follows is an attempt to unfold this issue.

\subsection{Emergence of new CIL: from the articulation of prescriptions of behaviour to the promotion of norms}

UN subsidiary organs define problems, frame solutions, articulate prescriptions, introduce these prescriptions as norms to the international community, clarify and promote the norms. Because

113 Cf with Draft Conclusions, UN Doc A/71/10, 106, Conclusion 12(2): “A resolution ... may provide evidence for establishing the existence and content of a rule of customary international law, or contribute to its development".

114 Hence, these activities do not serve only to "catalyse" state practice: they may, in fact, mould state practice because they may affect the identity of the states, the manner by which they define their own interests. Cf with Alvarez, above n 19, 258: "Describing GA or ILO resolutions as potential catalysts for generating customary law, perhaps the most popular way of describing their legal effect, does not begin to describe the diverse declarative, interpretative, condemnatory, or other functions of this kind of IO action". In contrast, M Wood, Third Report of the ILC Special Rapporteur on Identification of Customary International Law, UN Doc A/CN.4/682 (27 March 2015) [75]: "the conduct of international organizations may serve to catalyse state practice ... may prompt reactions by states, which may count as practice or attest to their legal opinions". In the same vein, Draft Conclusions, UN Doc A/71/10, 8990, Conclusion 4(3), Commentary, [9]; and 108, Conclusion 12, Commentary [7]. 
these activities are orientated at problem-solving, the type of prescriptions that they articulate often stretch the predominant understanding of the 'limits of the law'. For instance, recall the efforts of the 1998 working group on business and human rights, which the UN Sub-Commission on the Promotion and Protection of Human Rights established in response to multiplying reports of human rights abuses in the context of business activities, particularly within the extractive industries. ${ }^{115}$ The Sub-Commission was composed of experts from different regions who acted on their personal capacity, and it constituted the main subsidiary organ of the Commission on Human Rights ('CHR'). ${ }^{116}$ The working group submitted to the UN Sub-Commission in 2003, the so-called draft Norms on the Responsibilities of Transnational Corporations and Other Business Enterprises with Regard to Human Rights, which the Sub-Commission adopted. ${ }^{117}$ The document "solemnly proclaims these Norms on the Responsibilities of Transnational Corporations and Other Business Enterprises with Regard to Human Rights and urges that every effort be made so that they become generally known and respected". ${ }^{118}$ The 2003 Draft Norms were received with disapproval by the CHR ${ }^{119}$ which, as widely known, constituted a (political) subsidiary organ of the UN with a specific mandate (the promotion and protection of human rights). In fact, the refusal of the CHR to endorse the 2003 Draft Norms greatly jeopardised the evolution of the prescriptions-norms enshrined in that document. ${ }^{120}$ This example makes clear that a subsidiary organ (in this case, the Sub-Commission) may find room to define problems and push new prescriptions of behaviour forward; it also shows that new prescriptions that challenge firmly established politico-legal

${ }^{115} \mathrm{D}$ Weissbrodt and M Kruger, 'Norms on the Responsibilities of Transnational Corporations and Other Business Enterprises with Regard to Human Rights' (2003) 97(4) The American Journal of International Law 901-922; J G Ruggie, 'Business and Human Rights: the Evolving International Agenda' (2007) 101 The American Journal of International Law 819-820.

116 Office of the United Nations High Commissioner for Human Rights, Sub-Commission on the Promotion and Protection Human Rights (UN/2017) $<$ http://www.ohchr.org/EN/HRBodies/SC/Pages/SubCommission.aspx>.

117 'Norms on the Responsibilities of Transnational Corporations and Other Business Enterprises with Regard to Human Rights', Sub-Commission on the Promotion and Protection of Human Rights, 55 $5^{\text {th }}$ sess, Agenda Item 4, UN Doc E/CN.4/Sub 2/2003/12/Rev 2 (26 August 2003). (Hereinafter the '2003 Draft Norms')

118 Ibid Preamble.

119 Ruggie, above n 115, 819-820.

${ }^{120}$ However, this did stop NGOs and norm-entrepreneurs from promoting the 2003 Draft Norms outside the umbrella of the CHR. See J G Ruggie, Just Business: Multinational Corporations and Human Rights, Norton Global Ethics Series (WW Norton \& Company, 2013) 47-55 (The author explains the merits and flaws of the 2003 Draft Norms and his personal difficulty to free his mandate from the "shadow cast over it by the Norms", at 54). 
frameworks risk rejection by the political organs, especially if the procedure adopted for their formulation is perceived to be flawed. ${ }^{121}$

\subsubsection{Resolutions and specific activities}

Moreover, the example also shows that new prescriptions do not automatically transform into norms and, least of all, into legal rules. Should the 2003 Draft Norms have made its way to the text of a resolution of the $\mathrm{CHR}$, the resolution in question would have presented the prescriptions enshrined therein as valid social norms to the international community: the text of the 2003 Draft Norms ("solemnly proclaims these Norms on...") did not leave margin for doubt in this regard. ${ }^{122}$ Evidently, this would not have prevented states, notably those who eventually had voted against the adoption of the resolution, from rejecting the Draft Norms as valid social norms. In any case, the adoption of the resolution would have probably pushed the evolution of the Draft Norms further. ${ }^{123}$ Hence, resolutions of political organs may serve to provide evidence that norms have emerged. ${ }^{124}$

Hence, depending on the manner in which the prescription evolves, whether it triggers the emergence of a norm, and whether the norm acquires law character, the whole process may characterise, in hindsight, informal law-making. ${ }^{125}$ Indeed, years later, another effort led by John Ruggie, conducted with the full support of the political organs of the UN and through a complex consultative process with states, businesses and other NSAs, produced the Guiding Principles on Business and Human Rights ('GPBHR'), which the Human Rights Council ('HRC') endorsed through

121 See Ruggie, above n 120, 53 (Describing that the 2003 Draft Norms "pleased human rights NGOs but surprised governments and business because no intergovernmental body had approved them, nor had any government ratified them ... The UN Human Rights Commission resolved any possible confusion by stating in a formal resolution that the Norms had no legal standing”.

122 See above $\mathrm{n} 118$ and accompanying text).

123 Despite their rejection by the CHR, the 2003 Draft Norms continued to affect the debate on the topic among the different stakeholders, notably NGOs. Ultimately, John Ruggie had to clearly break with them. As he explains: "By now it had become clear that only a clean break would free my mandate from the shadow cast over it by the [2003 Draft Norms ... in the words of Edward Mortimer ... I committed 'Normicide"'. In Ruggie, above n 120, 54.

${ }^{124}$ Finnemore and Sikkink, above n 34, 892: "We can only have indirect evidence of norms just as we can only have indirect evidence of most other motivations for political action (interests or threats, for example)".

125 See the landmark study Alvarez, above n 19, 262 (The author concludes that "IO organs, not just select few, [act] as law-makers in some sense, even though few of them are given explicit authority to legislate or to recommend"). 
a resolution, ${ }^{126}$ formally presenting the principles as valid social norms. It is important to note the impossibility of pinpointing the instant at which a norm emerges-in fact, it seems that all one can hope is to find cues of its emergence. ${ }^{127}$ As Finnemore and Sikkink explain, "norms prompt justifications for action and leave an extensive trail of communication among actors that we can study." ${ }^{128}$ A resolution that clearly affirms a norm may constitute a strong cue that such a norm has emerged or is emerging within the community of states and IOs. Evidently, much will depend on the circumstances of its adoption and the respective vote tally: it is submitted that a resolution that is widely supported, notably if it takes the shape of a declaration, ${ }^{129}$ may provide strong evidence of the emergence of the norms, which the resolution affirms. Besides, although not legally binding, these resolutions often promote the inversion of the burden of proof in favour of the emerging norms. ${ }^{130}$ They may also establish an institutional environment that fosters compliance with these norms. ${ }^{131}$

Resolutions of this type likewise have the effect of triggering processes of clarification and promotion of the norm. Indeed, the work of the Commission on the Racial Situation on the Republic of South Africa and the Special Committee Against Apartheid were instrumental for the understanding of the meaning of apartheid because the organs made the practices of apartheid

126 Human Rights and Transnational Corporations and Other Business Enterprises, HRC Res 17/4, 33 ${ }^{\text {rd }} \mathrm{mtg}$, UN Doc A/HRC/RES/17/4 (16 June 2011) (Adopted without vote) [1] (hereinafter 'HRC Res 17/4'). See Ruggie, above n 120, 141 et seq (describing his efforts to secure the legitimacy of the consultative process he had carried out) and 157-159 (describing his efforts to secure the endorsement of the GPBHR by the HRC).

127 In fact, Ruggie argues that the corporate responsibility to respect human rights already existed as a "well-established social norm", and that all that the Framework and the GPBHR did was to provide "a more precise and commonly accepted definition of the corporate responsibility to respect human rights, what specific measures it entails, and how it can be linked more effectively with public-law construction of internationally recognised rights". See Ruggie, above n 120, 91.

${ }^{128}$ Finnemore and Sikkink, above n 34, 892.

129 Commission on Human Rights, "Use of the Terms 'Declaration' and 'Recommendation", Memorandum by the Office of Legal Affairs to the Commission on Human Rights, $18^{\text {th }}$ sess, UN Doc E/CN.4/L.610 (2 April 1962) 1-2: “In United Nations practice, a 'declaration' is a formal and solemn instrument, suitable for rare occasions when principles of great and lasting importance are being enunciated". Illustrating, Ruggie sought an endorsement by the HRC through a resolution adopted by consensus (without a vote). See above n 126 and accompanying text.

130 See above n 97 and below 142, and accompanying text. Also, Ruggie, above n 120, 124: "The endorsement by states ... gives official recognition to a norm that was previously grounded only in the realm of social expectations" and 157: "Strong Human Rights Council backing for the Guiding Principles was necessary for them to take root. Without it they would merely constitute yet another initiative vying for attention in a crowded field where none had reached scale".

${ }^{131}$ For instance, UN HRC Res 17/4 established a Working Group and a Forum on Business and Human Rights. See HRC Res 17/4, UN Doc A/HRC/RES/17/4, [6]-[17]. 
clear. ${ }^{132}$ Hence, they clarified the scope of the norm prohibiting it. While an HRC resolution endorsed the GPBHR, the meaning of the principles has become clear through the continued activities of subsidiary organs of the $\mathrm{UN}^{133}$ who often work with and provide assistance to domestic organs. Furthermore, this type of resolution, and the activities that it triggers, may strengthen the legitimacy of the new norm. ${ }^{134}$ Castañeda made a major contribution to this aspect by clarifying the importance of UN activities in giving an opportunity to developing states to participate in the processes of emergence of new CIL. ${ }^{135}$ The same argument is made by Alvarez, who notes that, in addition, IOs have fostered the legitimacy of NSA to influence law-making processes. $^{136}$

In addition, this type of resolution may have the effect of reversing the burden of proof. In this respect, Asamoah noted that there was a substantial difference between saying that resolutions of the GA had no binding effect, and saying that they had no legal effect: the scope of legal effect is, pursuant to him, broader than that of binding effect-and the latter is one aspect of the former. ${ }^{137}$ For example, in 2001, the International Law Commission held a debate about the ultimate recommendation that, under article 23(1) of its Statute, ${ }^{138}$ it should present to the GA in respect to the Draft Articles on State Responsibility. ${ }^{139}$ While some members supported the adoption of an international convention, others preferred the Assembly take note of the Draft Articles or adopt it in a resolution; and a third group suggested the Assembly adopt the text of the Articles in a declaration. ${ }^{140}$ Some of those who rejected the form of a treaty asserted that a "resolution or declaration adopted unanimously would be more effective than a convention adopted after many years of

132 Droubi, above n 31, 91 et seq. A Klotz, Norms in International Relations: The Struggle Against Apartheid (Cornell University Press, 1999) 39-54.

133 See Office of the United Nations High Commissioner for Human Rights, Business and Human Rights $<$ http://www.ohchr.org/EN/Issues/Business/Pages/BusinessIndex.aspx>.

134 Indeed, Legality of the Threat or Use of Nuclear Weapons (Advisory Opinion) [1996] ICJ Rep 226, 255 [70] ("a series of resolutions may show the gradual evolution of the opinio juris required for the establishment of a new rule").

135 Castañeda, above n 82, 38-48.

136 Alvarez, above n 19, 610-612.

137 O Asamoah, 'The Legal Effect of Resolutions of the General Assembly' (1963) 3 Columbia Journal of Transnational Law 210.

138 Statute of the ILC art 23(1): "The Commission may recommend to the General Assembly: (a) To take no action, the report having already been published; (b) To take note of or adopt the report by resolution; (c) To recommend the draft to Members with a view to the conclusion of a convention; (d) To convoke a conference to conclude a convention".

139 'Chapter IV: State Responsibility' [2001] II (2) Yearbook of the International Law Commission 20, 24-25.

140 Ibid 24 [61]. 
preparatory work and ratified by a small number of states" ${ }^{141}$ They claimed that such an act of the Assembly "would be seen as an authoritative study" that "would effectively place the burden on opposing states to prove that it was not binding" and that it would have a "decisive impact on international relations and the conduct of states, as evidenced by the jurisprudence of ICJ". ${ }^{142}$ As it is widely known, the Commission finally recommended that the Assembly take note of the Draft Articles and annexed their text to the resolution.

\subsubsection{Norm-entrepreneurship}

Likewise, at this stage organs and norm-entrepreneurs work on building the legitimacy of the norms. As already noted, the Secretary-General is the norm-entrepreneur par excellence of the UN system. ${ }^{143}$ Other actors, such as special procedures and members of subsidiary organs, may play that role as well—as the work of Eleanor Roosevelt and John Ruggie in the promotion of the UDHR and the GPBHR show. Norm-entrepreneurs make some arguments more salient. They may, for instance, justify the new norms as necessary for the task of pursuing the purposes and objectives of the UN. The higher the legitimacy that the new norm acquires, the lower the legitimacy that older norms with which the new norms may be at odds, retain. Norm-entrepreneurs often need to counter prevailing understandings. For instance, the strengthening of the UDHR and of the prohibition of apartheid implicated the weakening of state-centred and contractualist approaches to international law. ${ }^{144}$ A similar process may be in motion in respect to the GPBHE: as they become stronger, older paradigms, such as the impossibility of NSA to have rights and obligations in international law, weaken.

\subsubsection{The Secretariat-General and CIL}

While the Secretary-General may function as norm-entrepreneur, the activities of the SecretariatGeneral may serve to institutionalise the emerging rule. ${ }^{145}$ The Secretariat provides "the necessary

\footnotetext{
141 Ibid 24 [64] (emphasis added).

142 Ibid (emphasis added).

143 See generally, Schachter (1948) above n 83; Johnstone, above n 85; Droubi, above n 31.

144 See Droubi, above n 31, 91-95.

145 Similarly, Draft Conclusions, UN Doc A/71/10, 89, Conclusion 4, Commentary [6]: “The practice of secretariats of international organizations when serving as treaty depositaries, in deploying military forces ... or in taking positions on the scope of privileges and immunities ... might contribute to the formation, or expression, of rules of customary international law in those areas". However, note the caveat the ILC makes, and which I argue should not apply to the ascertainment of the formation of a rule: "The acts of international organizations that are not functionally equivalent to the acts of states are unlikely to be relevant practice" in ibid (emphasis added).
} 
lubricant in international machinery as well as an indispensable memory" to the other organs. ${ }^{146} \mathrm{It}$ comprises an international staff of more than 40,000 members based in different offices around the world and is responsible for a range of duties. Moreover, it counts on an impressive network of professionals and non-governmental organizations capable of providing assistance with respect to monitoring, reporting and administering technical support to states. Its work involves preparing documents in different languages, carrying out analysis (much of which requires detailed research), providing the means for monitoring situations on the ground, preparing reports, and making recommendations. In contrast with the personal involvement of the Secretary, a more nuanced manner of construing problems, framing solutions, and articulating and fixing the meaning of norms occurs in the ordinary work of the staff. Indeed, members of the Secretariat "very quickly become the rare experts on what specific activities the UN and member governments undertake". ${ }^{147}$ Consequently they can "insert a particular tone in the proceedings and on many occasions quietly inject their thought or take the initiative in offering government representatives ideas and data for mapping an altered or, for that matter, unchanged course."148

Hence, the Secretariat can embed the emerging norm in different manners into its activities and the activities of the UN organs and agencies. Evidently, it is constrained by the expectations of the UN organs and those of the states. Nevertheless, it has enough room to promote a norm through different channels.

\subsection{Cascade: managing compliance}

Higgins was right when she noticed a thin distance between compliance and opinio juris. However, not all compliance-inducing mechanisms aim at moulding the attitude of the state-while some mechanisms clearly aim at persuading states, others aim at changing their behaviour by relying either on instruments that create social pressures or on instruments of material sanctions and rewards. ${ }^{149}$ In the last two cases, the change of attitude may arise, but the main objective is the changing of behaviour. Nevertheless, pursuant to the principle of inertia, ${ }^{150}$ the observer can

\footnotetext{
146 L Gordenker, The UN Secretary-General and Secretariat (Routledge, 2010) 18.

147 Ibid.

148 Ibid.

149 A Chayes and A H Chayes, The New Sovereignty (Harvard University Press, 1995); R Goodman and D Jinks, Socializing States: Promoting Human Rights through International Law (Oxford University Press, 2013), and T Risse, S C Ropp, and K Sikkink (eds), The persistent power of human rights: From commitment to compliance (Cambridge University Press, 2013).

150 C Perelman, The New Rhetoric (Springer, 1971) 105; I G M Scobbie, 'The Approach to International Customary Law in the Study' in E Wilmshurst and S Breau (eds), Perspectives on the ICRC Study on Customary International Humanitarian Law (Cambridge University Press, 2007).
} 
reasonably expect that the behaviour prescribed or proscribed by the norm, once adopted or abandoned by the state, will remain adopted or abandoned because another change in behaviour will demand further justification.

In this framework, it is necessary to recall that UN organs may manage compliance-inducing mechanisms with the purpose of attaining acceptable levels of compliance. The managerial approach to compliance, so much in vogue now, ${ }^{151}$ was articulated by Chayes and Chayes in a landmark study that evidenced that UN organs make strategic use of different instruments to promote compliance with norms. ${ }^{152}$ This sheds some light on the concept of promulgative articulation of the norm: The sole fact that a resolution declares a new norm may, in theory, be enough for informing states that, thenceforth, their behaviour regarding the new norm will be subject of review. However, in practice, that is hardly enough to secure compliance, and it is important that the resolution in question establishes mechanisms of monitoring and reporting, which will give salience to non-compliant behaviour and enable criticism to arise. At this moment, the resolutions and activities of the UNSC become of fundamental importance.

\subsubsection{The SC and development of CIL}

The specific mandate and structure of the SC create a normative challenge and democratic deficit that make it difficult for the organ to influence the formation of $\mathrm{CIL}^{153}$-insofar as the definition of CIL is consistent with the mainstream definition. ${ }^{154}$ Indeed, these factors jeopardise the potential of SC resolutions to reflect general practice and opinio juris. In contrast, some factors seem to improve that potential, at least prima facie. Article 24 sets forth that the organ acts on behalf of all UN members, and articles 25 and 39 enable the organ to adopt—and enforce-mandatory

151 M Doelle, 'The Paris Agreement: Historic Breakthrough or High Stakes Experiment?' (2016) 6 Climate Law 1, 3 (The author contrasts the Kyoto Protocol with the Paris Agreement, highlighting that the latter is: "based on the idea that nation states can be moved toward action in the global interest through managerial approaches that build new norms of state behaviour. This managerial approach is based on transparency, a clear articulation of the collective goal, attention to the state of the science, and opportunities for interaction and information sharing, along with the flexibility to adjust to changing circumstances").

152 Chayes and Chayes, above n 149.

153 See, for all, the important contribution by O Corten, 'La Participation du Conseil de Sécurité à l' Élaboration, à la Cristallisation où à la Consolidation des Règles Coutumières' (2004) 37 Revue Belge de Droit International 552-566. (The author adopts a cautious approach to the topic, does not deny the potential that the organ has to affect the development of CIL, but rejects the characterisation of the SC as a type of "international jury, apte à se prononcer sur la création ou la réforme des règles juridiques les plus fondamentales du droit international").

154 As it is reflected in Draft Conclusions, UN Doc A/71/10. 
resolutions. In addition, the SC has developed the practice of adopting quasi-legislative resolutions, and of imposing the same type of obligations on states and NSAs in similar contexts. Both practices may give rise to generalisable rules. However, acting on behalf of all UN members cannot, in itself, provide evidence that states view the obligations, which the SC imposes, as CIL. Invoking the ability that the SC has to impose material sanctions will hardly help: states may comply without being convinced that they are legally required, least of all under CIL, to do so. Furthermore, when a significant number of states reject SC attempts to enforce its prior decisions, the states - rather than the organ - prevail. ${ }^{155}$ Even when the SC 'legislates', it—by definitioncannot create CIL because written laws do not automatically create CIL. ${ }^{156}$ Evidently, if states fail to protest resolutions of the SC, their failure may eventually be deemed to constitute acquiescence, which may constitute a crucial factor in the generation of new CIL. ${ }^{157}$ However, I argue that it is not only SC resolutions - and least of all only certain types of its resolutions - that can have this effect on the formation of CIL. In fact, it seems plausible to attribute the same potential to resolutions of the other UN political organs.

The present work offers an alternative approach that permits overcoming these challenges. Indeed, I suggest that we drop the rather formalistic approach that attempts to ascertain the effect of SC resolutions on the formation of CIL. Instead, I propose to ascertain the effect that the resolutions and activities have-not directly on CIL but-on the evolution and strengthening of specific norms. Broadly speaking, as the resolutions of all UN political organs, SC resolutions may introduce new norms, fine-tune the mechanisms for managing compliance with it and affirm that a norm is CIL. However, the major role that the SC performs in promoting a norm is by managing compliance through fixing the meaning of specific aspects of the norm; the monitoring of compliance with it, and the provision of technical assistance to organs of states. Indeed, the SC has developed complex institutions, in the form of Sanctions Committees, which are capable of inducing compliance. These institutions begin by identifying cases of non-compliance and the reasons for non-compliance. This allows them to go much further than the mere employment of material sanctions. They employ instruments of persuasion and the provision of technical

${ }^{155} \mathrm{~K}$ Tshibangu, 'La Décision de l'OUA de ne Plus Respecter les Sanctions Décrétées par l'ONU Contre la Libye: Désobéissance Civile des Etats Africains à l'Égard de l'ONU' (1999) 32 Revue Belge de Droit International 545. Generally, S Droubi, Resisting United Nations Security Council Resolutions (Routledge, 2014), chapters 3, 6, and 10 .

${ }^{156}$ For all, see Draft Conclusions, UN Doc A/71/10, 102, Conclusion 11.

157 Alvarez underlines that "at a minimum [SC resolutions] impose on those resisting such action the considerable burden of showing why something that was permissible previously is now either unwise or illegal" (Alvarez, above n 19,194). Again, resolutions of the other UN organs may create the same burden on recalcitrant states. 
assistance in order to tackle cases of non-compliance. For example, the SC established a sanctions regime to counter the financing of terrorism. This regime promoted the clarification of the meaning of the prohibition of terrorism in different, and unexpected, manners: on the one hand, it made it clear that the prohibition of terrorism included prohibition of any form of financing of terrorism; on the other, the challenges that the sanctions regime faced promoted the clarification of the relationship between the prohibition of terrorism with fundamental rights of individuals suspected of involvement with the financing of terrorism. To an extent, this regime has also been successful in monitoring and managing state compliance. Whether, in a specific given case, the Sanctions Committee contributes to changing the behaviour and attitude of states, and bringing them to comply, implement and support the norm in question-is a crucial empirical question that must be answered through case studies. Nevertheless, the theoretical framework above provides the student with the instruments necessary to ascertain, in empirical terms, the weight that the SC resolutions and activities have in the evolution of norms. ${ }^{158}$

\subsection{Late cascade of the new norm: affirming CIL}

Within the UN, the most obvious organ that serves as legal authority is the International Court of Justice. However, others may play the same role: the International Criminal Tribunal for Former Yugoslavia and the International Criminal Tribunal for Rwanda constituting easy examples. Nevertheless, political organs, notably principal political organs, may play this same role through certain types of resolutions. Rarely will a resolution bluntly and plainly affirm that a norm is a rule of CIL — and it may in fact state the opposite. ${ }^{159}$ In some circumstances, it may affirm that a norm is CIL without mentioning but merely implying that character. ${ }^{160}$ However, in exceptional circumstances, it may in fact affirm a norm as CIL. ${ }^{161}$ All UN political organs may function as

${ }^{158}$ Likewise, human rights treaty-bodies had been performing a similar role in the promotion of norms and fomenting of pressure on states. Notably, see the three stages of the life of the Commission on Human Rights (diffusion and standard-setting; monitoring; provision of technical assistance). To the same effect, new and more complex mechanisms have been employed by the UN HRC (Universal Periodic Review, Complaint Procedure, Special Procedures). Generally, A Clapham, Human Rights-A Very Short Story (Oxford University Press, 2015).

159 See, for example, SC Res 1816, UN SCOR, 63 ${ }^{\text {rd }}$ sess, 5902 nd $m$ tg, UN Doc S/RES/1816 (2 June 2008) [9] (stating that certain decisions made in the resolution did not constitute CIL). This resolution concerned Somalia and the same caveat was made in following resolutions in the same series.

160 The Crime of Genocide, GA Res 96(I), UN GAOR, $1^{\text {st }}$ sess, 55 th plen mtg, UN Doc A/RES/96(I) (11

December 1946) first operative paragraph: "Affirms that genocide is a crime under international law".

${ }^{161}$ In a number of resolutions, the GA affirmed that prohibition of torture is jus cogens and the prohibition of cruel, degrading and inhuman treatment, CIL. For instance, Torture and Other Cruel, Inbuman or Degrading Treatment or Punishment, GA Res 60/148, UN GAOR, 60 sess, 64th plen mtg, Agenda Item 
legal-authority in respect to the formal ascertainment of a norm as CIL. Indeed, the SC has affirmed that the "principle ... concerning the non-use of weapons against" aircraft in flight constituted CIL, ${ }^{162}$ and that the use of chemical, biological, or toxic weapons constitute a violation of CIL. ${ }^{163}$ However, this is different from the formal introduction of the norm to the international community that occurs at an earlier stage (emergence). ${ }^{164}$ For instance, the GA adopted the UDHR and the Declaration of Legal Principles Governing the Activities of States in the Exploration and Use of Outer Space. ${ }^{165}$ When the GA adopted these Declarations it formally presented the norms enshrined thereunder to the international community and this triggered a plethora of activities within the $\mathrm{UN}$. At the moment of their adoption, it is highly questionable whether the GA and states saw the norms in question as CIL. ${ }^{166}$ Hence, despite "solemnly declaring" those norms, the GA did something different from when it affirmed and strongly implied that, respectively, the prohibition of torture (and of cruel, degrading, and inhuman treatment) and the crime of genocide were CIL. The latter resolutions reflect a more mature stage in the life-cycle of the norms.

\section{Conclusion}

This work began by recalling Higgins' 'methods' though which states come to be bound by new norms. It emphasised two particular methods and, drawing on Charney's template, built on them to systematise the description of the formation of CIL and understand the importance that UN institutions play in promoting formation. It became clear that UN organs and institutions are capable of coordinating with state organs in the definition of problems and articulation of new prescriptions of behaviour. In these processes, states learn to identify problems as the latter are

71(a), UN Doc A/RES/60/148 (16 December 2005) preamble: "the prohibition of torture is a peremptory norm of international law and ... the prohibition of cruel, inhuman or degrading treatment or punishment is customary international law".

162 SC Res 1067, UN SCOR, 51 st sess, 3683 ${ }^{\text {rd }} \mathrm{mtg}$, UN Doc S/RES/1067 (26 July 1996) preamble, [6].

163 SC Res 620, UN SCOR, 43 ${ }^{\text {td }}$ sess, 2825 th $\mathrm{mtg}$, UN Doc S/RES/620 (26 August 1988) [2]. Note the strong mandate that this resolution ascribes to the SG to monitor cases of violation.

164 See above $\mathrm{n} 128$ and 129 and accompanying text.

165 Declaration of Legal Principles Governing the Activities of States in the Exploration and Use of Outer Space, GA Res 1962 (XVIII), UN GAOR, 28 th sess, 1280th plen $\mathrm{mtg}$, UN Doc A/RES/1962(XVIII) (13 December 1963).

166 B Cheng, 'United Nations Resolutions on Outer Space: “Instant” International Customary Law?', Studies in International Space Law (Oxford University Press, 1997) 138 et seq. However, this type of resolution may crystallise general principles of law. The confusion seems to arise whenever the scholar reduces the weight of the material element of the concept of custom. See B Simma and P Alston, 'The Sources of Human Rights Law: Custom, Jus Cogens, and General Principles', 12 Australian Yearbook of International Law 102. Contrast with Cheng, ibid. Hence, whilst the Declarations referred to above did not generate (instant) CIL, they may have 'promulgated' general principles of law. 
defined by organs of the UN. States learn to accept that the prescriptions of behaviour, which UN organs put forward, ought to be observed. Placed within their respective institutional frameworks, resolutions may have different effects for the evolution of the norm and its acquisition of CIL character. Indeed, resolutions may introduce the new norm, establish institutions that manage compliance with it, and affirm that it is CIL. In addition, increasingly specialised institutions may be involved in securing compliance with the new norm. The whole picture makes clear that the UN Charter offers a strong normative force, and the UN is a strong institutional reality, from which new norms may draw legitimacy. Based on the above, it seems possible to argue that norms that draw on the Charter are promoted through coherent efforts by the UN organs and do not overtly challenge the expectations of states that have potential to become CIL. Further studies are necessary to clarify specific topics - notably, the contribution that complex regimes' theories may help studies that purport to ascertain the role of domestic state and non-state actors in the formation of international norms, ${ }^{167}$ the impact of rapid onset events on the formation of CIL, ${ }^{168}$ and the different roles that the SC may play in fomenting the formation of CIL. ${ }^{169}$ Besides, further research may look at whether the UN, through the imposition of obligations on non-state actors, is promoting the emergence of a new paradigm in international law, which would make it possible to attribute rights and obligations to such actors. ${ }^{170}$

Finally, the paper began with quotations of two ILC Conclusions and feels it should end by returning to them. Generally, the present work supports both Conclusions. However, some considerations are necessary. Although the Draft Conclusions formally aim at facilitating the identification of CIL, they cannot avoid the question of its formation. ${ }^{171}$ Given the above, the expression "in certain cases" that opens Conclusion 4(2) seems too restrictive in respect to "formation" of CIL. ${ }^{172}$ I would suggest that the ILC revisit this Conclusion and drops that expression altogether. Further, I would suggest that, in the respective Commentary, the ILC emphasises that the ascertainment of the contribution of IOs to the formation of CIL requires empirical evidence on a case-by-case basis. Likewise, the present work largely supports Conclusion

\footnotetext{
167 See above $\mathrm{n} 51$ and accompanying text.

168 See above $\mathrm{n} 88$ and accompanying text.

169 See section 3.2.1 above.

${ }^{170}$ See sections 3.1 and 3.1.1 above.

171 Draft Conclusions, UN Doc A/71/10, 81, Conclusion 1, Commentary [4]: "The draft conclusions thus inevitably refer in places to the formation of rules; they do not, however, deal systematically with how rules emerge, or how they change or terminate".

172 Draft Conclusions, UN Doc A/7/10, 76 [62], Conclusion 4(2): "In certain cases, the practice of international organizations also contributes to the formation, or expression, of rules of customary international law".
} 
12(2). ${ }^{173}$ This having been said, I would suggest that resolutions contribute not only to the "development" but also to the "formation" of CIL. Having referred to "formation" of CIL in other tracts of the Draft Conclusions, the ILC could add the word to Conclusion 12(2).

173 Ibid 78 [62], Conclusion 12(2): “A resolution adopted by an international organization or at an intergovernmental conference may provide evidence for establishing the existence and content of a rule of customary international law, or contribute to its development". 